\title{
Familial Curriculum Making and a Home Reading Program
}

\author{
Sonia T. Houle \\ Parkland School District \\ Canada
}

\begin{abstract}
Home, community, and school experiences shape children's lives. In this paper I focus on the experiences of Matson, a young boy who was identified as a struggling reader in Grade 1, as well as the experiences of his mother and teachers who live alongside him. I inquire specifically into his family's curriculum making around home reading. This narrative inquiry is situated in a Deweyan perspective on education and in the curriculum studies literature, particularly within the concepts of lived curriculum and curriculum making. The four commonplaces of curriculum help me explore the making of curriculum in school and at home. While researching, my back and forth travel between school and home allowed me to notice and explore tensions. This multiperspectival approach also presents a shift from the teacher-centered perspective on children's education and curriculum making in school. This study shows how curriculum making in school and at home involves ongoing processes of assessment making and identity making, and illustrates how curriculum making shapes, and is shaped by, these factors. The relationship I developed with Matson's mother allowed me to know more about Matson's experiences. This perspective revealed secret stories and counterstories.
\end{abstract}

Sonia: $\quad$ How did you learn to read?

Matsoni: $\quad$ Hmmm, my mom taught me.

Sonia: $\quad$ Your mom taught you. How did she teach you?

Matson: $\quad$ She read and then we went. (Transcript, Sonia \& Matson, June 22, 2009)

The above conversation took place in June 2009 as Matson, a research participant who was in Grade 1, and I sat together at a table in a small room adjacent to the school library. I wanted to know whether he remembered how he had learned to read. Matson recalled his mother helping him learn. Later, in conversation with his mother, Marie, I learned that when Matson was in Kindergarten, he liked books, and also that she was expected to read to him (transcript, Sonia \& 
Marie, June 24, 2009). She remembered when Matson first brought books home in Grade 1, she read them to him. She forgot it was Matson who was supposed to read to her, until she received a note from his teacher, Mrs. Taylor, informing her that "Matson was really behind in reading... he should be reading [the books]" (transcript, Sonia \& Marie, June 24, 2009). Following that note, Marie tried to have Matson read to her.

We started to try to make him read; it was a struggle. Because he was behind... he'd get mad and throw the book down, or go, I don't want to read! I don't want to read! I would say you can read one [page], and I will read one. That worked better.... It just went really, really slow. (Transcript, Sonia \& Marie, June 24, 2009)

Marie confessed she had "messed up" by reading to Matson instead of having him read to her but recalled he "never had the urge to really try" (transcript, Sonia \& Marie, June 24, 2009). When asked to read to her, she noticed he got frustrated and gave up easily; she felt he did not want to read. At one point, Mrs. Taylor sent key words home for Matson to practise reading. Marie recounted how her husband was persistent in working with their son, and Matson seemed to be more willing to read books once he had learned to read the key words.

The above excerpts draw from a multiperspectival narrative inquiry into the experiences of Matson and Tiny Tim, two young boys identified as struggling readers ${ }^{\mathrm{ii}}$ by their Grade 1 teacher. The study was shaped in response to my experiences as a Grade 1 teacher alongside children who struggled with learning to read in Grade 1, and from conversations with acquaintances who had children who struggled to read. I began to notice tensions that developed when a child's reading progress did not occur according to grade level expectations. I remember a friend telling me that her daughter sadly shared, upon returning home from school one day, that unlike most of her classmates who read yellow books, she could only read green books. The daughter added, everybody knew what it meant to take green books home and was aware that she was "lagging" behind her classmates. My daughter, Annie, did not learn to read in Grade 1 and was aware of it. When I asked her if her teacher knew she could not read, Annie told me she did not know and made me promise to not tell her about it. I sensed shame in the girls' telling of their struggles in reading. I know as a parent, I worried about my daughter, just as my friend worried about her daughter. I wonder how such feelings might have shaped the girls' identities as learners and readers, and if it might have slowed down their progress in reading.

In this paper, I focus on understanding Matson's and his mother's experiences in relation with the school-prescribed home-reading programs over the course of his Grade 1 and 2 years. In this way, I draw attention to the tensions that emerged when Matson and Marie's familial curriculum making did not align with the school curriculum making. Attending to Matson's story highlights the importance of making space for children's familial curriculum making if we, as teachers, wish to succeed in creating educative experiences in school and at home.

\section{A Conversation with Theoretical Perspectives}

This section begins with an overview of Dewey's perspective on education, as well as my shifted understanding of curriculum and curriculum making inspired by Clandinin and Connelly's (1992) work. I also share Huber, Murphy, and Clandinin's (2011) conceptualization of familial curriculum making. 


\section{A Deweyan Perspective on Education}

Dewey's philosophy of education was influential in shaping my research puzzle around which my inquiry was threaded. His ontological and epistemological stance emerged from his view of experience:

The statement that individuals live in a world means, in the concrete, that they live in a series of situations.... An experience is always what it is because of a transaction taking place between an individual and what, at the time, constitutes his environment... The environment... is whatever conditions interact with personal needs, desires, purposes, and capacities to create the experience which is had. (1938, pp. 43-44)

In Dewey's view, education is life; life is experience. Furthermore, experience is non-static, forever changing, and relational. It was this relational nature of his view on experience which first drew me toward Dewey's ideas as they strongly resonated with how I understand learning. His emphasis on the continuity of experience, that is, that "every experience lives on in further experiences" (1938, p. 27), helped me understand how past experiences influence present and future experiences. Even though throughout Dewey's work there is attentiveness to education leading into the future, Dewey's (1938) emphasis that education be for today, not a preparation for the future, also resonated with my beliefs that school experiences need to be related to the present moment of each child's life. An educative experience today should prepare us for tomorrow. In this way, Dewey helped me to wonder about how children who were struggling to read experience each present moment.

\section{Coming to Understand Curriculum Making}

As Connelly and Clandinin (1988) bring Dewey's understanding of experience alongside dominant understandings of curriculum, they invite us to imagine that curriculum "can become one's life course of action. It can mean the paths we have followed and the paths we intend to follow" (p. 1). In these terms, the idea of curriculum becomes personal or specific to a person. However, for me, as for many teachers, curriculum is most commonly understood as the thick document written by policy makers and passed to school boards and teachers to be enacted through learning activities. This "mandated curriculum",iii is intended to relate to general collectivities "where students [and teachers] become faceless others" (Aoki, 1993, p. 265). As I gradually shifted my thinking about who makes curriculum, and how it is made, I turned to Clandinin and Connelly's (1992) view of curriculum

as an account of teachers' and children's lives together in schools and classrooms... a view in which the teacher is seen as an integral part of the curricular process... in which teacher, learners, subject matter, and milieu are in dynamic interaction. (p. 392)

Such an understanding makes visible, or possible, curriculum as something alive and in motion. I now think about curriculum making in school as the co-composition of the life in the classroom. Along with Aoki (1993), who awakened me to a lived curriculum particular to each student and teacher, Clandinin and Connelly (1992) helped me re-imagine making curriculum in school. As a young teacher, I often felt frustrated by limitations I perceived from the mandated curriculum. I felt trapped and directed by the sacred stories of school, ${ }^{\text {iv }}$ which impose a specific curriculum.

What I did not understand then was that there were multiple curricula in my classroom: the mandated, the planned, and the lived. ${ }^{\mathrm{v}}$ Connelly and Clandinin (1988), and earlier Schwab (1962), identified teacher, learner, subject matter, and milieu as four commonplaces that are part of curriculum making and need to be considered when discussing curriculum making. Within the interaction of these four commonplaces, curriculum is made and lived out (Clandinin \& 
Connelly, 1992; Clandinin et al., 2006). In this way I came to understand that the lives of teachers and children meet in schools and classrooms - the milieus - around a subject matter. This junction shapes a complex intersection continuously shaped and reshaped in the meeting of the lived experiences of teachers and students. The lived curriculum that emerges around the study of a subject matter is shaped by the milieus of teachers' and children's lives (Clandinin \& Connelly, 1992). In this way, and alongside Aoki's (1993) sense of the multiplicity of curriculum in "production" in the classroom, I felt encouraged to move the mandated curriculum from its central position and to give people's stories ${ }^{\mathrm{vi}}$ more space in curriculum making. This shift, in my understanding of curriculum making, shaped how I positioned my research into the experiences of young children struggling to read.

Furthermore, Murphy saw the impact that working closely with students' parents had on his curriculum making in schools (Murphy \& Pushor, 2004). He described ways in which these relationships "shifted the living out of a unidirectional and hierarchical school agenda to the living out of an agenda in relationship with parents in reciprocally beneficial ways" (p. 234). As I, too, over my years of teaching grew to pay attention to parents in schools, I also came to understand how they were involved in supporting making curriculum. However, it was not until I read Huber, Murphy, and Clandinin (2011) that I awakened to "familial curriculum making" which they describe as

an account of parents'/families' and children's lives together in homes and communities where the parents and families are an integral part of the curricular process in which families, children/learners, subject matter, and home and community milieus are in dynamic interaction. (pp. 7-8)

They call readers to see familial curriculum making "as equally important to the negotiation of lives as the in-classroom, in-school curriculum making" (Huber et al., 2011, p. 8).

However, as two different curriculum-making places (in the home/community and in schools) are attended to and considered in relation, emerging tensions help us understand how curriculum making is shaped. Attention to the tensions makes visible the "gaps and silences [children] experience living in these two curriculum-making places" (Huber et al., 2011, p. 108). Furthermore, inquiring into curriculum making in school and within familial places helps us understand how assessment making and identity making ${ }^{\text {vii }}$ are connected to curriculum making (Huber et al., 2011). As I gradually came to know Matson, I began to understand how curriculum making is interwoven with assessment and identity making in his life curriculum making. As a guest in Matson's familial places, I learned about his curriculum making in school and at home.

\section{Engaging in Narrative Inquiry}

Narrative inquiry is the study of experience. It is a research methodology grounded in Dewey's (1938) notion of experience, and in Clandinin and Connelly's (2000) narrative view of experience, which is "a collaboration between researcher and participants, over time, in a place or series of places, and in social interaction with milieus" (p. 20). Clandinin and Connelly (2000) drew upon Dewey's conception of experience and their narrative view of experience to develop a research methodology called "narrative inquiry." Experience, considered a storied phenomenon (Crites, 1971; Clandinin \& Connelly, 2000; Carr, 1986), is understood as lived and told stories. It is the storied experiences, both the lived and told, which narrative inquirers study. Following Dewey, experience is shaped through interaction in situations across time and place. In this way, narrative inquirers understand people as living in storied landscapes. These storied landscapes 
are shaped by nested social, cultural, and institutional narratives which, in turn, shape people's lives and are also, at times, shaped by the lives of the people who live in those landscapes (Clandinin \& Connelly, 2000).

Epistemologically, as a narrative inquirer, I understand knowledge as embedded in lived experiences nested in various milieus, times, and relationships. I privilege "individual lived experience as a source of insights useful not only to the person himself or herself but also to the wider field of social science" (Clandinin \& Rosiek, 2007, p. 49). Inquiring narratively viii brought me to hear and tell stories participants shared with me, and to co-compose stories from living alongside them. The stories presented in this paper were composed either from the participants' words, or from my interpretation of their recorded "actions, doings, and happenings, all of which are narrative expressions" (Clandinin \& Connelly, 2000, p. 79). Through the sharing of lived and told stories, the participants and I developed relationships, as narrative inquirers are always in relationship with participants (Clandinin \& Rosiek, 2007; Clandinin, 2013): narrative inquirers are people in relation, studying the experiences of people in relation (Clandinin \& Connelly, 2000). Within our evolving inquiry relationships, field texts (data) were co-composed with the participants. I inquired into these field texts within a metaphorical "three-dimensional narrative inquiry space," which includes the dimensions of: sociality (interaction between the social and personal dimensions); temporality (past, present, and future); and, place (Clandinin \& Connelly, 2000, p. 50). Attending to participants' and my lived experiences, I thought in four different directions in relation with our lived and told stories: inward (personal—emotions, hopes, and values) and outward (social - the environment, the external conditions); backward and forward (temporal); all along I was attentive to where experiences happened (place) (Clandinin \& Connelly, 2000). Throughout this non-linear process of "thinking with stories" (Clandinin, 2013) I inquired into my experiences alongside the participants' experiences. The participants and I told new stories and retold earlier stories. We tried to understand our lived and told stories differently and hoped to live them otherwise (Clandinin \& Connelly, 2000).

\section{Participants}

The study took place at Ramsey Elementary School, located in a suburb of a Western Canadian city where I met the participants: two boys, Tiny Tim and Matson; their mothers, Morgan and Marie; and their Grade 1 and Grade 2 teachers, Mrs. Taylor and Mrs. Henry. In addition, the students from their classes were part of the study as they interacted with the primary participants.

\section{Timeline and Overview}

My field work started in May 2009. I spent three mornings weekly in the Grade 1 classroom as a participant observer, helping when needed. In June 2009, Mrs. Taylor and I chose two boys she identified as struggling readers. I then started individual conversations with the boys, their mothers, and Mrs. Taylor. In late June 2009, I began negotiating my relationship with Mrs. Henry, the Grade 2 teacher, who would teach Tiny Tim and Matson in September. I had conversations with each mother and teacher during the summer. In early September 2009, I started school visits in the boys' Grade 2 class, where I spent time developing relationships with the students and with Mrs. Henry. I resumed my conversations with Tiny Tim and Matson later in September, and had more conversations with their mothers and their teachers (Grades 1 and 2) during the following months. I participated in classroom life until February of 2010, but continued to have conversations with the mothers and the boys until the end of the school year. I 
Familial Curriculum Making and a Home Reading Program

negotiated the boys' narrative accounts with all the participants during the fall of 2011. In this paper, I focus on one boy, Matson.

\section{Field Texts}

The participants and I co-composed multiple kinds of field texts: field notes from classroom participation; transcripts of tape-recorded conversations with Matson, his teachers, and his mother; drawings Matson made during our conversations; artifacts of Matson's class work; pertinent school documents (school mission statements, report cards, tests), and my research journal. During the conversations I had with the participants, we engaged in topics that emerged in the ongoing conversations.

\section{From Field Texts to Research Texts}

I organized my field texts chronologically in binders. I read field texts and I underlined every piece I considered significant about Matson. I attended carefully to the different voices involved (Houle, 2010) and was mindful of the three dimensional narrative inquiry space (time, place, and sociality). I thought about Matson, who he was, how the field texts spoke about him, how he storied himself, and what seemed important to him. I thought about how his mother and his teachers storied him, and what seemed important to them. I paid attention to tensions and gaps as well. This process helped me decide which threads resonated in his stories and which ones I would inquire into and write about in his narrative accounts. I wrote a narrative account of Matson's experiences in Grade 1 and another for Grade 2.

I negotiated the narrative accounts with Matson and with Marie to ensure they agreed with my representation of their experiences. Marie and I read together the two narrative accounts. Considering Matson's young age, I could not simply read them with him; I needed to represent them in a form he could access. Drawing on Anthony Browne's (1998) Voices in the Park, in which he writes a story about people going for a walk at the park, I wrote a book titled, Matson's Story (Houle, 2012). Browne wrote the story in four parts, including: the perspectives of a mother, a father, a boy, and a girl. I found his concept inspiring, considering the multiple perspectives in my study. For Matson's Story, I selected parts from the narrative accounts I felt best represented Matson's stories of himself and of school, and his mother's and teachers' stories of him in Grades 1 and 2. The different perspectives (Matson, Marie, Mrs. Taylor, and Mrs. Henry), from which I wrote, represented my understanding of Matson's stories lived and told. I chose pictures to illustrate each page and printed a copy to share with Matson. Neither he, nor his mother, asked me to make changes during the negotiations of the accounts. I shared the accounts with the two teachers as well. Both requested minor word changes which we negotiated and replaced.

\section{Ethical Considerations}

Ethical considerations permeated all aspects of the study (Clandinin \& Connelly, 2000) including: the negotiation of the entries in the classrooms and the homes, the strong focus on developing and attending to relationships with the participants, the co-composition of field texts, and the negotiation of research texts with participants.

Living alongside Matson and his teachers at school and visiting his mother at home required being mindful of the multiple relationships involved in the study. When I wrote the narrative accounts, I carefully pieced together the stories they told me and the stories we cocomposed together. I meticulously picked words considerate of the well-being of all participants. 
At times though, their well-being seemed at risk, as I felt what I wrote from certain perspectives might hurt other participants' feelings once they read them. I constantly reflected on the advantages and disadvantages of including specific fragments of stories. I composed narrative accounts in collaboration with participants and shared them, keeping in mind everyone's wellbeing.

\section{Awakening to Tensions in the Meeting of Familial and School Curriculum Making}

In the introduction, I shared a story Matson told me about learning to read with his mother. His words speak of the familial curriculum Marie made with her son. Matson recalled his mother supporting him in trying to learn to read. The familial curriculum Marie made with Matson showed another layer in his lived experiences, another world in which he lives (Huber et al., 2011). In this section, I share a narrative account of Matson's life curriculum making which includes both familial and school curriculum making, as well as tensions noticed in the two places of home and school.

Being in relation with Marie gave me access to Matson's familial place and to the stories he lived and told there. I met Marie in her home, saw her neighbourhood, met her children and their pets. I was introduced to the environments in which her family lived every day. I saw family pictures on the walls, shoes by the door, clothes hanging on the railings, piles of books on tables, toys on floors, schedules on refrigerators, and food on countertops. The newer neighbourhood where Matson and Marie lived was next to a creek, a treasured place of play and discovery for Matson. I was privileged to be invited into Matson and Marie's home, and to have the opportunity to develop what I considered a friendship with Marie and Matson.

The home and neighbourhood, an interconnected milieu where Matson lived with his family, represents one of Schwab's (1962) four commonplaces for thinking about curriculum. In the context of their lives at home and in the community, I saw the parents and the children as both learners and teachers. Marie learned from being alongside Matson that giving him time after school to relax and eat helped him be ready to read books. Matson learned from his mother how to read when "she read and [they] went" (transcript, Sonia \& Matson, June 22, 2009). The two commonplaces, teacher and learner, take on a different meaning when examined at home rather than at school, where teachers are usually storied as the teachers, and the children are storied as learners.

Subject matter, a commonplace in making curriculum, is usually mandated in schools. In its mandated form, it is not coordinated (Schwab, Westbury, \& Wilkof, 1978) with the other commonplaces, such as the particular of the teachers and the learners and the milieus in which curriculum is made. Curriculum developers neither know the children nor the teachers for whom they develop the curricula; they do not know their milieus either. The curricula are developed for a generic mass, in a nonspecific milieu called the classroom; they are not for the particular. Teachers know aspects of their students' lives; they know the school milieu and know themselves (the teachers). When they make curriculum with students, they have the possibility to attend to the four commonplaces of teacher, learner, subject matter, and milieu (Schwab et al., 1978). Historically, though, subject matter has occupied a central position in curriculum making in schools. The mandated subject matter remains at the centre and is often the starting point when people talk of making curriculum. Within this milieu then, teachers often fail to attend to the four commonplaces, as their focus remains on the subject matter commonplace. 
At Marie and Matson's home, I saw familial curriculum making enacted in the following situation. Matson liked to play in the creek behind their house where he rode his bike, built a tree house, and went sledding. Marie supported her son's activities by providing sports equipment and tools. In this example, I see Marie attending to the four commonplaces in curriculum making; she considered the learner and his interest in, and need for, being active and creative; as the teacher, she facilitated her son's actions by giving him time to play and making available materials she could supply; she cleverly used the milieu, the creek, which afforded an ideal environment for the activities Matson enjoyed; lastly, she attended to the subject matter, physical activity and health, curiosity and joy, among others.

Marie seemed to intuitively know about these commonplaces Schwab (1962) insists we consider when making curriculum. She often took account of the subject matter alongside the learners, the teachers, and the milieus in the home and broader community; she knew her children and their milieus. When she made curriculum in the home, Marie knew many of the commonplaces. She might not be an expert with the school subject matter, but knowing the other three commonplaces gave her a considerable advantage in making significant and educative curriculum with her children. In Marie's home, subject matter was probably considered more like Schwab (1962) argues it should be considered an equal in relation to the other commonplaces. When Marie considered the subject matter of home reading and made curriculum with her son and her family, I imagine she attended to the other three commonplaces, the milieu, the teacher and the learner.

Huber et al. (2011) suggested we "decentre the view of curriculum making occurring in schools and classrooms and make visible the other places and people with whom children are also involved in curriculum making" (p. 2). A child's curriculum, or life course of action, past journeys, and future plans (Connelly \& Clandinin, 1988), are not composed exclusively in schools; it is a journey that unfolds over time and in a variety of places, alongside multiple individuals. In schools, teachers, educators, and policy makers have been privileged as curriculum makers (Huber et al., 2011), and schools are most commonly storied as "the" places where children are educated. A child's education "includes schooling but [it is] life-long and broader-reaching than schooling" (Pushor, 2010, p. 24). I highlight familial curriculum to show the intricacy in children's co-composition of their life curriculum and to offer possibilities for shifting how curriculum is made in schools.

\section{Matson and Marie's Tensions with Home Reading in Grade 1}

Home-reading programs are common in schools; many teachers include them in their language arts program as support for the development of reading skills and the love of reading. They usually are assigned and included in children's homework. Both Mrs. Taylor and Mrs. Henry, the Grade 2 teacher, had a home-reading program for students. In Grade 1, Marie shared with me that Mrs. Taylor reminded her that Matson should be reading to her. She recalled how she "messed up" because she had been reading to her son and did not realize he should have been reading to her. Her comment that Matson "never had the urge to really try" (transcript, Sonia \& Marie, June 24, 2009) made me wonder whether she chose to read to him because he did not offer to read. Did she think reading to Matson was the right thing to do with him? Matson was happy his mother read to him; however, in Grade 1, children were supposed to start reading on their own. When Mrs. Taylor noticed Matson was behind, she alerted Marie. Following Mrs. Taylor's lead, Marie tried to encourage Matson to read to her. She found he gave up easily. Even though Mrs. Taylor carefully chose the level of books for her students, Matson did not seem to 
enjoy reading them. Mrs. Taylor tried to support Marie in helping him learn to read by giving her key words Matson could practice to read, to help with fluency. Marie, and especially her husband, Jeff, diligently worked with Matson to help him learn to read the key words. Marie seemed happy with her son's reading at the end of Grade 1, but remarked later in Grade 2 that she felt he never was comfortable reading books in Grade 1, and thought he "struggled" until the end of that year (transcript, Sonia \& Marie, February 16, 2010).

Matson's home-reading story in Grade 1 shows how the school curriculum making shaped Marie's familial curriculum making with her son; she had read to him until Mrs. Taylor's note. Some might think Matson did not want to make the effort to read when he let his mother read to him. However, as I continue to think with about Matson's and Marie's storied experiences, I am reminded of Martha George, the teacher in Goldstein's (1997) study, who, although she did not always leave it up to the children to choose, she believed their choices informed her on where they were in terms of academic and personal development. Did Marie interpret Matson's choice to listen to her read as an indicator of where he was in his reading development? Was Marie making assessment with her son and responding accordingly?

Marie mentioned she "messed up" when she learned Matson should be reading to her. Even though I believe she thought he was not ready to read on his own, she complied with Mrs. Taylor's instructions and made Matson read to her. In doing so, she privileged the school curriculum making over her familial curriculum making. I know Marie had a good relationship with Mrs. Taylor and respected her expertise. However, Marie recalled how difficult it was to make her son read; he gave up easily, felt frustrated, and did not want to read. Was this really how Marie wanted to live with Matson? I wonder if she questioned herself after she heard from Mrs. Taylor that Matson was behind. Did she feel she had not properly supported Matson in learning to read?

\section{Indelible Connections among Curriculum Making, Identity Making, and Assessment Making in a Child's Life Composition}

Gradually, I realized that assessment making was indelibly connected with the identity Matson was composing as he made a life curriculum shaped by his experiences at home, in the community, and in school. In this section, I trace these indelible connections.

\section{Matson's Worries}

Marie told me her son worried about failing Grade 1.

For a while he'd say, I'm failing at school... I'm failing. I will have to do Grade 1 again... He said that, even up to lately. I don't know where he's getting that... I can't get it out of him... I don't know if he feels he's behind the other kids. I don't know where he sits in there, but he comes with this idea. I did tell him, why do you think that, and he didn't know... He knows what the other kids do. (Transcript, Sonia \& Marie, June 24, 2009)

Marie had seen improvement with her son's reading and was puzzled to hear him say he thought he was failing at school. She did not know how he came up with this idea. During a conversation I had with Mrs. Taylor in August, she noted that:

[Matson's] reading... didn't come along and develop the fluency and the confidence that I was hoping... The reality is that Matson... [is] struggling... [He's] not achieving where you'd want [him] to be, to easily say to [his] parents [he's] okay. (Transcript, Sonia \& Mrs. Taylor, August 13, 2009) 
Familial Curriculum Making and a Home Reading Program

As I thought about how Mrs. Taylor did not think Matson was reading at the "expected" level for the end of Grade 1 alongside Marie's story of Matson's sense that he was failing Grade 1, I wondered if Matson knew how his teacher assessed his reading. Did he hear Mrs. Taylor tell his mother that he was "really behind"? Did his mother discuss Mrs. Taylor's comment with him, or in his presence? How did Matson perceive his father's persistence with helping him learn to read the key words? Did he sense that something was wrong? While Marie was unaware of how he constructed his story of failing Grade 1, I wonder if the home and school curriculum making shaped his assessment making. Marie was not comfortable knowing her son thought he was failing. She worried about how he perceived himself and about his identity making. She wondered if he felt he was not as good as his classmates. Matson's comment to his mother shows me, that already in Grade 1, he was assessing his performance; he was an assessment maker.

\section{Doing Better in Grade 2}

At the beginning of Grade 2, Marie was pleased to hear a shift in Matson's assessment making. When she asked, "[h] ow the work was going? He said, it's easier than Grade 1. ... How come? ... I don't know. Is the reading hard? ... No, I can do it" (transcript, Sonia \& Marie, September 9, 2009). Marie seemed happy to inform me that Matson felt successful with the curriculum Mrs. Henry was making with the students in Grade 2. She added that Matson "was surprised that [he could] read... He said it's easy... He's happy because he can do better. He's not finding it hard" (transcript, Sonia \& Marie, September 9, 2009). When Marie asked Mrs. Henry how Matson was doing she was told that Matson "gets his work done... he tries hard, he's doing fine" (transcript, Sonia \& Marie, October 14, 2009). Marie thought her son's printing was better; she found that he did not "struggle too much, [and seemed] to be able to spell words" (transcript, Sonia \& Marie, October 14, 2009). In this way, Matson's assessment making early in the year, and Mrs. Henry's assessment of his work both seemed to shape Marie's assessment making of Matson.

\section{Reading as a Family}

In Grade 2, for home reading, Matson had to read the books he chose from the school library which his class visited once a week. Marie found that some of the library books Matson brought home were too difficult for him. She talked about what Matson liked to read; he liked his father's Mustangix magazine, the series of Guinness World Records and the Ripley's Believe It or $N o t^{x}$ books, but needed help to read these texts (transcript, Sonia \& Marie, February 16, 2010). I believe Matson had difficulties finding library books he liked and that he could read. Monica, his sister, was in Grade 1. She loved to come home every day and read her books ${ }^{\mathrm{xi}}$ to her mother. Marie was pleased and amused to see Monica so motivated. Matson, on the other hand, surprised her with his interest in reading Monica's books (transcript, Sonia \& Marie, October 14, 2009). She explained:

I'll sit down with [Monica] to do her book. He's like, I [want to] read it... I make her read it first and then he reads it and he sees how fast he can read it now, so he's quite excited. (Transcript, Sonia \& Marie, October 14, 2009)

Marie thought her son wanted to impress his sister, and recalled Matson saying "I can read faster than you Monica" (transcript, Sonia \& Marie, October 14, 2009). She considered her son to be very competitive and thought he was more motivated to read now than before his sister started to read. She was happy to see Matson more interested in reading; she believed Matson felt like this 
because he could read better (transcript, Sonia \& Marie, October 14, 2009). Matson's assessment making shaped his familial curriculum making.

The familial curriculum Marie made with her children allowed for each child's experience to be the starting point (Huber et al., 2011). She listened to Monica, who wanted to be heard reading, and involved Matson who, according to Marie, wanted to show he could read better than his younger sister. She did not discourage him from reading the Grade 1-level books Monica brought home; she welcomed her son's eagerness to read them, even though he was in Grade 2.

Marie seemed comfortable making curriculum in the way she did with her children in the context of home reading. Woven into her curriculum making was Marie's assessment making; she saw her son read and be interested in reading; he did well on his report cards; she did not notice any struggle; did not receive alarming calls from his teacher; and her son told her he was "a really good reader" (transcript, Sonia \& Marie, March 24, 2010). She did not worry about him. Marie was happy to know her son felt he was a good reader.

Marie mentioned she believed her daughter Monica motivated Matson to read more. She explained Monica "was always grabbing a book ... [wanting] everybody to hear her [read] ... [reading] as loud as she [could] ... and [asking]: what does this spell 'w-h-i-l-e', and [wanting] someone to tell her" (transcript, Sonia \& Marie, February 16, 2010). Marie found Matson supportive of his sister, as he would sit down and help her: "she [read] out loud and he just kind of [sat] there ... sometimes he [was] watching TV and [helped] her if she [didn't] get a word" (transcript, Sonia \& Marie, February 16, 2010). The curriculum she made with her children allowed for Matson to be a mentor to his younger sister, which made Marie an identity maker with her son.

Marie's support for Matson's interest in reading Monica's books contributed to his positive self-image and increased confidence, because he experienced success reading those books. Marie put Matson's experience more in the centre of curriculum making. She was mindful of the subject matter, which in this case was home reading, and the milieu, a milieu that involved Monica who wanted to read to anyone in the house. As the teacher in that situation, Marie attended to the four commonplaces to suit her family: it suited Matson's reading level, it suited Monica's need for attention, and it suited her to see her son embrace reading and feel successful. Marie made "responsive curriculum making that began with the child's... knowing, with [his] ongoing negotiation of [his] stories to live by"xii (Huber et al., 2011, p. 40). Marie's curriculum making alongside her children was responsive to, and was shaped by, her family's needs (Huber et al., 2011), needs that changed over time. Marie shaped the familial space in response to how Monica and Matson responded to their home reading program.

\section{A Shared Secret Story?}

Mrs. Henry wanted the students in Grade 2 to identify a goal towards which they would work during the student-led conferences in November. Matson's goal was "home reading" (field notes, December 2, 2009). Marie reported that the goal set for her son was to write down the books he read at home. As this goal was set Mrs. Henry indicated Matson needed to write them himself. Marie seemed to agree with giving Matson the responsibility to do so. Despite his mother's and teacher's wish that he write down the books he read, I do not believe Matson ever did it.

Although neither Matson nor Marie wrote the titles of the books Matson read at home, Marie indicated that he read a lot. Mrs. Henry encouraged the students to write down the titles of 
the books they read on a reading sheet and asked them to bring the sheet back to school. She rewarded students who followed her instructions with small prizes. Marie did not think Matson was interested in the stickers he could earn upon returning a completed reading sheet (transcript, Sonia \& Marie, March 24, 2010). Matson did not document his home reading; Monica, on the other hand, did so consistently. Marie explained how it was easier with Monica because she had a book per night while Matson read "whatever, whenever" (field notes, November 4, 2009). I assumed it meant more to Monica to document her reading than it did to Matson. Maybe Matson was not interested in the stickers his teacher gave them. I wonder, though, whether Matson and Marie skipped documenting his reading because writing down titles of Grade 1-level books could have caused problems. Would Mrs. Henry have indicated to Marie that Matson was behind, as Mrs. Taylor had when he was in Grade 1? Did Marie decide to keep that story secret from the teacher because she believed it would bump against her familial curriculum making in which she saw her son progress as a reader? Did she, consciously or unconsciously, keep her familial curriculum making silent from the school? I wonder if Matson forgot or refused to write down the titles because he knew he was reading "easy" books and wanted to keep that secret. Did he worry his teacher would not approve of his choices? Did he worry other students would laugh at him if they saw which books he read? Did he avoid documenting his reading so the only story of him as a reader would be the one he co-composed with Monica and his mother? I wonder how this aspect of his identity making shaped his curriculum making.

\section{Marie's Counterstory}

Marie noticed how Monica was catching up to Matson in reading ability. From our conversation, I did not sense she worried about Matson even though his younger sister could read almost as well as he did. She saw Matson for who he was, a developing and progressing reader, a boy who felt good about his accomplishments. She did what she believed would help Matson move forward. Although Marie compared her children's reading skills, she did not seem to think they needed to be reading at specific predetermined levels. I believe she saw Matson's reading development on a continuum. Through the familial curriculum making with her children, Marie composed a counterstory ${ }^{x i i i}$ to the dominant assessment story of school. At school, the teachers were required to assign each child with a predetermined "grade level of achievement" (Government of Alberta). Marie focused on her children's progress and respected their individual growth. She pursued her familial curriculum making with Matson in regard to home reading even though it did not follow the school curriculum making. What inspired her, I wonder, to live and compose such a familial story, a story she did not silence in her living with Matson? Would Marie be considered uncooperative if the teachers at school knew what she was doing with Matson? What about the parents who might believe in familial curriculum making different from the one the schools suggest but hesitate to do so and let the school curriculum making override the familial curriculum making? Do they think teachers are the experts in making decisions regarding curriculum making? What if parents understood making curriculum where the teachers (the parents in familial curriculum making) know the learners (the children) better than anyone else? How would parents negotiate school curriculum making within their familial curriculum making if they positioned themselves as equals with the professionals (the teachers, the administrators, the policy-makers)? 


\section{Reflections}

The multiple perspectives included in this research were critical in helping me cocompose accounts of Matson's experiences in school and at home, and in so-doing, understand his experience of learning to read. Some of Matson's lived experiences, particularly those he shared only with his mother, like his worries about failing Grade 1, would not have been told had I not been in relation with her, attending to her stories. Being in relation with Marie positioned me closer to Matson; it helped me know him better and hear his perspective through his mother's words. Connecting with children's lives is something I believe is important in making curriculum with them. In this way, my experiences alongside Matson and Marie might encourage teachers to develop more relationships with children's parents.

Shedding light into the familial curriculum making contributed to my understanding of how Matson experienced learning to read. Looking at curriculum making across home and school places, and at the travel children do between these two places, is what allowed me to notice and explore tensions. Listening to Matson, both in school and at home, tell his lived curriculum, and listening to his mother tell her stories from home showed in a concrete way a shift from the teacher-centred perspective on children's education and curriculum making in schools. Curriculum making in school and at home involves ongoing processes of assessment making and identity making. Moving back and forth between the two places within which Matson lived shows how assessment making and identity making both shape and are shaped by curriculum making in schools and at home. Access to these multiple perspectives helped me attend to Matson's life as a whole.

Children experience school in various ways. They construct stories of school and stories of themselves at school and at home. Those stories are not always educative. Matson's story of worrying about failing Grade 1 is an example. Teachers are not always aware of those stories. In response to her son's fears, Marie made a curriculum with him in which she adjusted the reading program to better suit his needs, although doing so meant living a counterstory to the school curriculum making. Unfortunately, this remained a secret story. Would the teachers have made curriculum differently had they known how Matson experienced school and reading? What would Mrs. Taylor have done had she known Matson worried he might fail? How would Mrs. Henry have responded to the difficulties Matson experienced in reading the books he brought home? What would have been possible, had Marie and Matson shared more of their stories with the teachers?

My goal in sharing Matson's and Marie's stories was to bring attention to children's and parents' stories. I hope their stories may help awaken teachers to children's experiences, thereby supporting them to understand and shape curriculum making in schools, and consequently, in homes, as the two curriculum-making places (Huber et al., 2011) shape and are shaped by each other.

Considering how schools have been positioned as the focal point of children's education, I hope that Matson's and Marie's storied experiences might contribute to the discourse around shaping space for the familial curriculum making, one of the places where children make curriculum, a place often invisible in schools. Decentring school curriculum making and laying familial curriculum making alongside will, I imagine, support teachers in understanding children's lives. The telling of children's, parents', and teachers' stories, and the meeting of the two curriculum-making worlds will, I imagine, support understanding "children... as shaped by both familial and school curriculum making" (Huber et al., 2011, p. 151). Attending to children's 


\section{Familial Curriculum Making and a Home Reading Program}

multiple curriculum-making worlds will, I imagine, support educators and parents to think about who they are in relation with each other. I am hopeful that this kind of wakefulness about children's lives may result in more educative experiences as children travel back and forth between school and home. 


\section{References}

Aoki, T. (1993). Legitimating lived curriculum: Towards a curricular landscape of multiplicity. Journal of Curriculum and Supervision, 8(3), 255-268.

Browne, A. (1998). Voices in the park. New York, NY: DK Pub.

Carr, D. (1986). Time, narrative and history. Bloomington, IN: Indiana University Press.

Clandinin, D. J. (2013). Engaging in narrative inquiry. Walnut Creek, CA: Left Coast Press.

Clandinin, D. J., \& Connelly, F. M. (1992). Teacher as curriculum maker. In P. W. Jackson (Ed.), Handbook of research on curriculum (pp. 363-401). New York, NY: MacMillan.

Clandinin, D. J., \& Connelly, F. M. (1996). Teachers' professional knowledge landscapes: Teacher stories - stories of teachers - school stories - stories of schools. Educational Researcher, 25(3), 24-30. doi: 10.3102/0013189X025003024

Clandinin, D. J., \& Connelly, F. M. (2000) Narrative inquiry: Experience and story in qualitative research. San Francisco, CA: Jossey-Bass.

Clandinin, D. J., Huber, J., Huber, M., Murphy, M. S., Murray-Orr, A., Pearce, M., \& Steeves, P. (2006). Composing diverse identities: Narrative inquiries into the interwoven lives of children and teachers. New York, NY: Routledge.

Clandinin, D. J., \& Rosiek, J. (2007). Mapping a landscape of narrative inquiry: Borderland spaces and tensions. In D. J. Clandinin (Ed.), Handbook of narrative inquiry: Mapping a methodology (pp. 35-76). Thousand Oaks, CA: Sage Publications.

Connelly, F. M., \& Clandinin, D. J. (1988). Teachers as curriculum planners: Narratives of experience. New York, NY: Teachers College Press.

Connelly, F. M., \& Clandinin, D. J. (1999). Shaping a professional identity: Stories of educational practice. New York, NY: Teachers College Press.

Crites, S. (1971). The narrative quality of experience. Journal of the American Academy of Religion, 39(3), 291-311. doi:10.1093/jaarel/xxxix.3.291

Dewey, J. (1938). Experience and education. New York, NY: Collier MacMillan.

Goldstein, L. S. (1997). Teaching with love: A feminist approach to early childhood education. New York, NY: Peter Lang.

Government of Alberta, CA, Ministry of Education. (n.d.). Grade Level of Achievement Reporting. Retrieved March 15, 2012, from http://education.alberta.ca/admin/resources/gla.aspx 
Guinness (Firm). (2008). Guinness world records 2008. Bantam Books.

Houle, S. T. (2010). Not making the grade: A narrative inquiry into Timmy's experiences with the mandated curriculum. in education, 16(2), 30-40. Retrieved from http://ineducation.ca/ineducation/article/view/98

Houle, S. T. (2012). A narrative inquiry into the lived curriculum of Grade 1 children identified as struggling readers: Experiences of children, parents, and teachers. Unpublished doctoral dissertation, University of Alberta, Edmonton, Alberta, Canada.

Huber, J., Murphy, M. S., \& Clandinin, D. J. (2011). Places of curriculum making: Narrative inquiries into children's lives in motion. Bingley, UK: Emerald.

Lindemann Nelson, H. (1995). Resistance and insubordination. Hypatia, 10(2), 23-40. doi:10.1111/j.1527-2001.1995.tb01367

Murphy, B., \& Pushor, D. (2004). Parent marginalization, marginalized parents: Creating a place for parents on the school landscape. Alberta Journal of Education, 50(3), 221-232.

Mustang Monthly. Retrieved from http://www.mustangandfords.com/mustang-monthly-magazine/

Pushor, D. (2010). Parent engagement in mathematics is just not possible. Or is it? Journal of the Saskatchewan Mathematics Teachers' Society, 2(1), 20-32. Retrieved from http://www.smts.ca/files/journal/vinculum2(1).pdf

Ripley’s Inc. (2008). Ripley’s Believe It or Not! Special Edition 2008. NY: Scholastic.

Schwab, J. (1962). The teaching of science as enquiry. In J. J. Schwab and P.F. Brandwein (Eds.), The teaching of science (pp. 3-103). Cambridge, MA: Harvard University Press.

Schwab, J. J., Westbury, I., \& Wilkof, N. J. (1978). Science, curriculum, and liberal education: Selected essays. Chicago, IL: University of Chicago Press

\section{Notes}

i The participants' names and the school name are pseudonyms. The participants chose their pseudonyms.

ii The children I focused on in this study were children who, toward the end of Grade 1, were identified as struggling readers by their teacher. The delay in learning to read only referred to the expectations, in regard to time, of the sociocultural and institutional narratives. I did not do any diagnostic testing. For this study, I did not wish to refer to disabilities, an extensively researched topic in the reading field. I chose to use the term struggling readers because that was how they were "labelled," or storied, in the school where I did my field work.

iii The school mandated curriculum, also referred to as a program of studies, is the curriculum provided by the Ministry of Education. It is an official document in which learning outcomes for students are listed. Teachers are required to teach the mandated curriculum under the School Act (in the Canadian province where I live and teach). iv Sacred stories of school refer to the ways dominant theoretical stories are assumed to drive practice in schools and to shape the lived stories of the people who live on the school landscape. They are named sacred stories because they have the quality of sacred stories as they are often unquestioned (Clandinin \& Connelly, 1996). 
${ }^{\mathrm{v}}$ While I am aware that there are other types of curricula in the literature, and used in schools, for this study, I focus on the mandated, planned, and lived.

${ }^{\mathrm{vi}}$ Stories represent people's lived experiences.

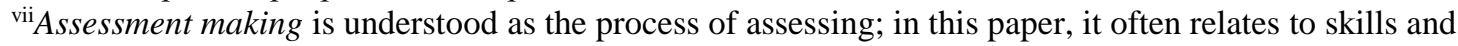
dispositions, while identity making is the process of shaping an identity.

viiiBy inquiring narratively I mean inquiring within the stories lived and told of the participants and the researcher. The term narratively relates to the stories.

${ }^{\text {ix }}$ Mustang is a brand of car.

${ }^{x}$ There are numerous books from the Guinness World Records and Ripley's Believe It or Not Series.

${ }^{x i}$ In Monica's Grade 1 class, her teacher, Mrs. Taylor, had a classroom library. The levelled books the children took home to read to their parents came from that collection.

xii Stories to live by is a narrative term used by Connelly and Clandinin (1999) to refer to the relationship between the stories, the knowledge, and the contexts that shape people's identity. It is a narrative, experiential way to think about identity.

xiii Lindemann Nelson (1995) calls a counterstory a story that disrupts the dominant one and helps bring shifts and changes (Clandinin et al., 2006).

Sonia T. Houle, PhD., teaches Grade 2 children in a French Immersion program with the Parkland School District. Narrative inquiry guides her pedagogy. She also taught as an instructor at the University of Alberta. Sonia was the recipient of the 2013 Faculty of Education Outstanding Doctoral Dissertation in Teacher Education Award at the University of Alberta; she is still deeply connected with the Centre for Research for Teacher Education and Development (CRTED).

Email: sonia.houle@ualberta.ca 